\title{
Correction to: Building 3D Lithofacies and Depositional Models Using Sequential Indicator Simulation (SISIM) Method: A Case History in Western Niger Delta
}

\author{
Kehinde David Oyeyemi ${ }^{1} \cdot$ Mary Taiwo Olowokere $^{2} \cdot$ Ahzegbobor Philips Aizebeokhai $^{1}$
}

Published online: 20 April 2018

(c) King Fahd University of Petroleum \& Minerals 2018

\section{Correction to: Arabian Journal for Science and Engineering https://doi.org/10.1007/s13369-018-3212-4}

The original version of this article unfortunately contained mistakes. The authors' family and given names were interchanged. The names in correct sequence are given above.

The original article has been corrected.

The original article has been corrected.

The original article can be found online at https://doi.org/10.1007/ s13369-018-3212-4.

\footnotetext{
Kehinde David Oyeyemi

kdoyeyemi@yahoo.com;

kehinde.oyeyemi@covenantuniversity.edu.ng

1 Applied Geophysics Unit, College of Science and Technology, Covenant University, Ota, Nigeria

2 Department of Geology, Obafemi Awolowo University, Ile-Ife, Nigeria
} 